\title{
Problem-Based Learning Model Based on Naturalist Intelligence to Realize Student's Science Literacy: Needs Assessment Survey
}

\author{
Ari Suryawan ${ }^{1}$, Suyanta $^{2}$, Insih Wilujeng ${ }^{3}$ \\ \{arisuryawan.2020@student.uny.ac.id ${ }^{1}$ \} \\ Doctoral Program, Postgraduate Yogyakarta State University ${ }^{1,2,3}$
}

\begin{abstract}
This research is a type of quantitative research that uses a quantitative descriptive research design that aims to find out; (1) How big is the understanding of elementary school teachers on Problem Based Learning, Multiple Intelligence Theory and Science Literacy. (2) To what extent is the urgency of developing a learning model with these 3 aspects for science learning in elementary schools. The population is all Muhammadiyah elementary school teachers in the Magelang district. The sample used in this study were 50 elementary school teachers who teach in grades 4,5 and 6 . The data analysis technique used was descriptive quantitative, the results showed the understanding of elementary school teachers in problem-based learning, learning theory of multiple intelligence, and literacy. science, shows more than $50 \%$ of teachers understand and learn this. With the urgency in developing the model, more than $60 \%$ of the sample agreed with the development of the elementary science learning model.
\end{abstract}

Keywords: problem based learning, multiple intelligence, science literacy

\section{Introduction}

Education is the pillar of culture and the main foundation for building a nation's civilization. The fourth point of the Sustainable Development Goals is the improvement of the quality of education. Awareness in developing the quality of education will determine the quality of welfare in the future. A country that has succeeded in achieving a high level of cultural and technological progress must have a very good quality of education. Stipulation of Government Regulation Number 32 of 2013 concerning Amendments to Government Regulation Number 19 of 2005 concerning National Education Standards and Permendikbud No. 81A concerning Curriculum Implementation is expected to encourage the improvement of the quality of education management in education units which leads to efforts to improve the quality of education, particularly through the implementation of the new curriculum, namely the implementation of the 2013 Curriculum in Elementary Schools. Ornstein \& Hunkins stated that "successful curriculum implementation results from careful planning, which focuses on three factors: people, programs, and processes [1].

In the 2013 curriculum, teachers are required to act as facilitators whose job is to stimulate or provide stimulus, help students to want to learn on their own and formulate their understanding, while the role of students is to be active in learning and digesting lessons and teachers are expected to use a variety of learning methods that allow students to practice thinking, traditional creative activities, develop freedom of thought, issue ideas, foster the 
enjoyment of working together so that teachers are required to provide a variety of learning activities that have implications for a variety of learning experiences so that students can develop their competencies independently [2][3].

The development of learning must be adapted to the conditions of students in the classroom, besides that it must also pay attention to the circumstances around the school for teachers to be able to package learning that is backgrounded and focuses on the lives of students themselves Demands for implementing the 2013 curriculum where teachers are proficient in developing learning. The learning model is a learning model where the teacher can help students to get or obtain information, ideas, skills, ways of thinking, and express their ideas. In addition, they also teach how students learn [4]. The implementation of science education in Indonesia is still low, this can be seen from the results of the science literacy of Indonesian children. Scientific literacy is characterized by scientific work, and the three major dimensions of scientific literacy defined by PISA are science content, scientific process, and scientific context.

Based on the above, elementary science learning should be improved by doing: 1) science learning is not only learning the concepts but also accompanied by the development of scientific attitudes and skills (domain knowledge and cognitive processes); 2) science learning provides a learning experience that develops the ability to reason, plan and conduct scientific investigations, using the knowledge that has been learned to understand natural phenomena that occur around them; 3) revitalize "scientific process skills" to develop observation skills, plan investigations, interpret data and information (narratives, pictures, charts, tables) and draw conclusions 4) combine multiple intelligence learning theories according to students' learning styles.

One of the developments of science learning in elementary schools is by using Problem Based Learning. Problem-based learning helps students to get information already in their minds and construct their knowledge about basic and complex knowledge. Problem-based learning has student-centered characteristics, designed based on real problems that encourage students to build rich knowledge of contextual mathematical concepts through a series of constructive questions [5] on the other hand the Problem-based Learning model produces better results on metacognitive skills and independent learning students when compared with conventional learning models [6]. The science learning process cannot stand alone, there must be a combination of multiple intelligences that match the student's learning style. In general, science learning is closely related to naturalistic intelligence. Naturalistic intelligence is defined as the skill to recognize and categorize species, both flora, and fauna, in the environment, and its ability to cultivate and utilize nature and preserve it [7]. In the 2013 Curriculum, apart from the learning outcomes to be achieved, scientific literacy can also be added in science. Scientific literacy is now a demand that must be mastered by every individual. Students who have scientific literacy skills will apply their knowledge to solve problems both in personal, social, and life situations [8]. The first thing in applying scientific literacy is to see students' involvement in learning based on experiences experienced in life-related to knowledge. students obtained from scientific literacy [9]. Based on the description above, in the development of learning in elementary schools, it is necessary to develop a model that focuses on Multiple Intelligence and can improve students' scientific literacy. 


\section{Methods}

This research is quantitative research with a descriptive survey research method, the survey method is used to obtain data from a certain population that is natural, but the researcher collects data by distributing questionnaires where the researcher does not provide treatment as in the experiment [10]. Collecting data using a questionnaire survey. The data obtained will be analyzed using descriptive analysis. The analysis is described by the calculation results in the form of numbers and from these results will be explained descriptively. Based on this type of descriptive research approach, the researcher will describe and analyze the conditions regarding the need for developing learning models. In this study, the participants used in the survey to develop this model were the teachers of the Muhammadiyah Primary School in Magepang Regency totaling 50 people. This teacher teaches in grades 4 to 6 .

\section{Results and Discussion}

\subsection{Conditions of Understanding Aspects of model development}

Of the 50 elementary school teachers who filled out the main comprehension questionnaire via a google form, each main aspect had 10 questions which were then displayed using the average sum of all the questionnaires, the results can be seen in Table 1 .

Table 1. Conditions of understanding aspects of model development

\begin{tabular}{clccc}
\hline \multirow{2}{*}{ No } & \multicolumn{1}{c}{ Main Aspects } & \multicolumn{3}{c}{ Conditions } \\
\cline { 3 - 5 } & Understanding Problem Based Learning & 10 & Medium & High \\
\hline 2 & Understanding Multiple Intelligences & 25 & 20 & 11 \\
\hline 3 & Understanding Science Literacy & 23 & 24 & 13 \\
\hline
\end{tabular}

*Number of teachers every class

At this stage the researchers surveyed 50 teachers, the results can be analyzed that the Problem Based Learning learning model requires development, this is caused because the science material in elementary school is very complex and requires an innovative learning model. Problem-based learning needs to be applied to elementary school children to improve students' scientific abilities. Through PBL learning, students are trained to think critically to solve real problems in groups. Learning activities with the PBL model affect students' environmental attitudes because the problem-solving process in PBL learning encourages students to care about their environment [11]. In the aspect of the theory of multiple intelligences, the majority of teachers have a less comprehensive understanding of this theory, this is because most teachers do not add references to their knowledge of psychological development in terms of learning. However, almost half of the population requires the Multiple Intelligence aspect in the implementation of learning.

At this stage, the teacher realizes that every child has the potential for intelligence that can be developed, especially naturalist intelligence as the main way to discuss science according to the environmental conditions of each student. In the opinion of the naturalist intelligence teacher, it is very necessary because it invites students like a researcher, this will affect the enthusiasm and interest of students in learning science. Students also enjoy doing research. They 
are attracted to various species of living things and animals. They enjoy reading magazines about nature and traveling [12]. In the aspect of scientific literacy, it also supports this to be used as a goal in science learning. The 2013 curriculum for implementation in elementary schools also emphasizes adding other competencies such as elementary school literacy. The majority of teachers agree because, at the next level of education, scientific literacy is a stage that must be mastered by students.

\subsection{Survey on the urgency of learning model development}

Table 2. Survey on the urgency of learning model development

\begin{tabular}{|c|c|c|c|c|c|}
\hline \multirow{2}{*}{ No } & \multirow{2}{*}{$\begin{array}{c}\text { Developmental } \\
\text { Aspects }\end{array}$} & \multirow{2}{*}{ Grade } & \multicolumn{3}{|c|}{ Conditions } \\
\hline & & & Disagree & Agree & Strongly agree \\
\hline \multirow[t]{3}{*}{1} & Problem Based & 4 & 5 & 8 & 7 \\
\hline & Learning needs to be & 5 & 3 & 10 & 4 \\
\hline & developed & 6 & 1 & 8 & 4 \\
\hline \multirow[t]{3}{*}{2} & Multiple intelligence & 4 & 3 & 7 & 10 \\
\hline & combinations for the & 5 & 4 & 5 & 8 \\
\hline & learning process & 6 & 2 & 7 & 4 \\
\hline \multirow[t]{3}{*}{3} & Realizing scientific & 4 & 2 & 16 & 2 \\
\hline & literacy & 5 & 2 & 7 & 6 \\
\hline & & 6 & 3 & 4 & 6 \\
\hline
\end{tabular}

*Number of teachers every class

The survey results in the aspect of Problem Based Learning need to be developed, especially in grades 4,5 , and 6 where more than $50 \%$ of teachers agree on the development of the model. Problem-based learning needs to be developed according to the characteristics of elementary school students and the demands of the current situation. Development can be done with the use of media or other devices. The learning process using a problem-based learning process makes each student have the responsibility to solve problems on student worksheets to connect daily life, problem-based learning also ensures all students understand what they have done, such as problem clarification, group problem-solving techniques, gathering information, and sharing information data and discussing for problem-solving. The problem-based learning model of science learning can be applied by teachers in elementary school learning in grades 4,5 , and 6 to develop scientific literacy. The selection of the problem-based learning model based on scientific literacy must pay attention to the characteristics of the material and the characteristics of students. Problem-Based Learning is a learning process that exposes students to a real problem that spurs students to research, describe, and find solutions [13].

At the stage of developing problem-based learning on the theory of multiple intelligences, it is very necessary to do, the majority of teachers agree on this linkage, this is because the concrete operational stage for children aged 10 to 12 years is very necessary. Teachers have understood that children's learning styles are indispensable for information processing. The development of learning based on the theory of multiple intelligences will have an impact on their enthusiasm to learn optimally. Learning with problem-based learning based on multiple intelligences will attract students' interest in learning materials. The learning process with this approach has an impact on students because they have a high interest in learning so that the material taught using multiple intelligence-based learning will be more meaningful [14].

Based on Table 2., the teacher agrees with the effort to realize scientific literacy by developing a problem-based learning model. This learning model has stages to train students to 
think critically. Problem-based learning makes students analyze and conduct scientific experiments systematically, this can increase students' scientific literacy. Experimental activities using practicum tools will improve and increase students' scientific literacy [15]. Problem-based learning activities are adapted to reform and create innovative direct instruction approaches in developing new situations such as scientific literacy which is currently the benchmark for PISA.

\section{Conclusion}

The conclusion in this study is that in implementing the 2013 curriculum and the dynamics of science learning in elementary schools, it is necessary to develop a problem-based learning model combined with multiple intelligence theory to realize students' scientific literacy. Elementary school teachers provide assessments for the development of learning models to prepare their students to adapt to $21^{\text {st }}$ century learning and the various supporting competencies.

\section{Acknowledgment}

Our gratitude goes to the Muhammadiyah elementary school teacher in the Magelang district who has stated so that research data can be collected properly. To the Yogyakarta State University Postgraduate Program which has provided a forum for researchers to conduct research development.

\section{References}

[1] A. C. Ornstein and F. P. Hunkins, Curriculum : Foundations, Principle, and Issues. England: British Library Cataloguing-in-Publication Data, 2018.

[2] R. Wahyuni, T. Berliani, and U. P. Raya, "JMSP (Jurnal Manajemen dan Supervisi Pendidikan)," vol. 3, pp. 63-68, 2019.

[3] A. dan Poerwti, Panduan Memahami Kurikulum 2013. Jakrta: PT Prestasi Putrakarya, 2013.

[4] A. \& M. A. Fawaid, Model-Model Pengajaran. Yogyakarta: Pustaka Pelajar, 2011.

[5] W. Malmia et al., "Problem-Based Learning As An Effort To Improve Student Learning Outcomes," Int. Educ. Stud., vol. 11, no. September 2019.

[6] A. D. Kesumawardani, ") Model : How Does It Influence Metacognitive Skills and Independent Learning ? Problem-Based Learning ( PBL," vol. 1, no. 1, pp. 27-32, 2021.

[7] M. Yaumi, S. Fatimah, S. Sirate, and A. A. Patak, "Investigating Multiple Intelligence-Based Instructions Approach on Performance Improvement of Indonesian Elementary Madrasah Teachers," 2018.

[8] M. Wati and S. Miriam, "Pengembangan Instrumen Kognitif Literasi Sains Pada Pokok Bahasan Tekanan Di Kelas Viii Smp Kota Banjarmasin,” J. Ilm. Pendidik. Fis., Vol. 1, No. 3, Pp. 113-125, 2017.

[9] J. Hidayati, F., "Penerapan Literasi Sains dalam Pembelajaran IPA di Sekolah Dasar untuk Meningkatkan Kemampuan Berpikir Kritis Siswa dalam Memecahkan Masalah," in Seminar Nasional Pendidikan. Banjarmasin 24 Maret 2018, 2018.

[10] Sugiyono, Metode Penelitian Kombinasi (Mix Methods). Bandung: Alfabeta, 2014. 
[11] A. Kaharuddin, "Effect of Problem Based Learning Model on Mathematical Learning Outcomes of 6 th Grade Students of Elementary School Accredited B in Kendari City Effect of Problem Based Learning Model on Mathematical Learning Outcomes of 6 th Grade Students of Elementary School Accredited B in Kendari City," no. September 2018, 2019.

[12] M. Sami and H. Sert, "Primary school 5th-grade science and technology lesson book' s investigation of multiple intelligence theory," Procedia - Soc. Behav. Sci., vol. 174, pp. 2577-2581, 2015.

[13] F. Rozi and S. Prawijaya, "The Development of Problem-Based Learning Model with Scientific Literacy Approach in Elementary School," vol. 208, no. Icssis 2018, pp. 230-233, 2019.

[14] N. S. Widyastuti and P. Pujiastuti, "Pengaruh Pendidikan Matematika Realistik Indonesia (Pmri) Terhadap Pemahaman Konsep Dan Berpikir Logis Siswa," J. Prima Edukasia, vol. 2, no. 2, p. 183, 2014.

[15] P. A. T. P. and I. Listiani and Primary, "Guided experiments book based on SETS ( Science, Environment, Technology, and Society ) to empower science literacy for elementary school students Guided experiments book based on SETS ( Science, Environment, Technology, and Society ) to empower sci," IOP Conf. Ser. J. Phys., vol. 1318, 2019. 